Available online at: http://journal.uinsgd.ac.id/index.php/kh

Khazanah Hukum, Vol. 2 No. 3: 92-99

DOI: $10.15575 /$ kh.v2i3. 8167

\title{
KEWENANGAN ATRIBUSI, DELEGASI DAN MANDAT
}

\author{
Moh Gandara \\ Kementerian Agama Kabupaten Purwakarta, Jalan KH. Abdurahman No. 2, Purwakarta 41114. \\ Email: Gandaraabi2@gmail.com
}

\begin{abstract}
The preparation of this journal wants to explain the things related to the authority of attribution, delegation and mandate. The theory is intended is a system of authority given by the state and is regulated in order to run and create good governance. is in the authority system that is regulated in laws in the government system in Indonesia. Likewise with the restrictions on the authority that is associated with a period or the time of falter of auth ority area and scope of the auth ority or material. The dispute over the authority was completed by the lastinternal government official by the President, and if it did not produce an agreement resolved by the Constitutional Court and legislation. Use qualitative method this research found The ban on abuse of authority is exceeding the authority, acting arbitrarily, actions outside the scope of authority, confuse the authority, exceed the term of office or the time limit of the authority, goes beyond unauthorized and canceled regional boundaries Supervision by the government's internal and can submit to the State Administrative High Court, the verdict from the State Administrative Court is final and binding.

Keywords: Attribution, Delegation, Mandate, Authority
\end{abstract}

\begin{abstract}
ABSTRAK
Penyusunan jurnal ini ingin memaparkan hal yang terkait dengan kewenangan atribusi, delegasi dan mandat. Teori dimaksud merupakan sistem wewenang yang diberikan oleh negara dan diatur demi menjalankan dan menciptakan pemerintah yang baik. ada dalam system kewenangan dalam peraturan undang-undang dalam system pemerintahan di Indonesia. Begitu juga dengan pembatasan kewenangan yang dikaitkan dengan masa atau waktu dan batasan berlakunya wilayah kewenangan dan cakupan bidang atau materi kewenangan. Sengketa kewenangan diselesaikan oleh intern pejabat pemerintahan terakhir oleh presiden, dan apabila tidak menghasilkan mupakat diselesaikan oleh mahkamah konstitusi dan undang-undang. Menggunakan metode penelitian kualitatif penelitian ini menemukan bahwa Larangan penyalahgu naan kewenang yaitu melewati wewenang, bertindak sewenang-wenang, tindakan diluar cakupan wewenang, mencampuradukan wewenang, diluar masa jabatan atau batas waktu berlakunya kewenangan, diluar batas wilayah tidak sah dan dapat dibatalkan oleh putusan pengadilan. pengawasan oleh intern pemerintah dan dapat mengajukan ke pengadilan tinggi TUN, putusan dari Pengadilan TUN bersipat final dan mengikat.
\end{abstract}

Kata kunci : Atribusi, Delegasi, Mandat, Wewenang

\section{PENDAHULUAN}

Dalam sistem permerintahan di republik indonesia dalam undang-undang nomor 30 tahun 2014 tentang administrasi negara bahwa ada teori yang dikenal dengan istilah atribusi, delegasi, dan mandat. Ketiga istilah itu mengandung makna yang hampir mirip yaitu merupakan kewenangan yang diberikan negara untuk menjalankan suatu roda pemerintahan agar pemerintahan itu berjalan sesuai tujuan yang diamanatkan oleh konstitusi tetapi pada kenyataan nya ketiga istilah itu memangberbeda, (Adiwilaga et al., 2018; Sastra, 2017) atribusi yaitu wewenang pemerintah yang diberikan oleh pembuat undang-

\footnotetext{
* Copyright (c) 2020 MOH Gandara
}

This work is licensed under a Creative Commons Attribution-ShareAlike 4.0 International License. 
undang kepada badan/lembaga pemerintah selain itu atribusi yaitu wewenang pemerintah yang diberikan oleh undang-undang kepada badan/lembaga pemerintah untuk melaksanakan keputusan (beschikking) yang langsung berasal dari undang-undang sebagai legalitas formalnya, pembentukan kewenangan dan pemberianya kepada organisasi tertentu. Delegasi yaitu pelimpahan kewenangan pemerintah yang sudah ada (dari kewenangan atribusi) dari organisasi pemerintah kepada organisasi pemerintah lainya. Mandat yaitu kewenangan yang diberikan oleh badan/lembaga pemerintah kepada badan/lembaga lain atas namanya dan atas izin dari pemegang wewenang dan biasanya dalam hubungan rutin terjadi dari atasan kepada bawahan kecuali dilarang tegas oleh undang-undang. Dalam rangka meningkatkan kualitas pelayanan terhadap masyarakat penyelenggara pemerintah, badan dan atau pejabat pemerintah dalam menggunakan kewenangannya harus mengacu pada asas-asas umum pemerintahan yang baik dan mengacu kepada perundang-undangan (Azhar,2015).

Beberapa penelitian terdahulu seperti penelitian HSB \& JULIANTHY (2019) meneliti tentang pelaksaan kewenangan atribusi pemerintah daerah menghasilkan pelaksanaan kewenangan atribusi harus bersinergi dengan pemerintahan daerah, Rokhim (2013) meneliti tentang kewenangan pemerintahan dalam konteks negara kesejahteraan (welfare state) menghasilkan wewenang pemerintah yang hanya mengacu pada peraturan perundang-undangan dipandang sudah out of date, dan penelitian dari Wicaksono \& Purbawa (2018) hutang negara dalam reforma agraria studi implementasi mandat 9 juta hektar tanah indonesia yang menghasilkan sinergi dengan lintas kementerian m utlak diperlukan sebab secara nyata akses reform tidak bisa bergerak secara linier tetapi memerlukan integrasi yang holistik dan sistematis dengan kementerian lain.

Dari beberapa penelitian terdahulu masih belum adayang menganalisistentang studi kepustakaan dari masing - masing kewenangan, penterjemahan bahasahukum sangat penting untuk di jelaskan secara detail dan tidak bermakna ganda, karena akan menyulitkan penggerak roda organisasi apabila mereka sulit untuk membedakan setiap kewenangan yang ada sehingga dapat terjadi suatu kesalahan dalam operasedur pekerjaan, tujuan dari artikel ini adalah sebagai bahan kajian dan memperjelas setiap pengertian dari kewenangan khususnya kewenangan atribusi, delegasi dan mandat.

\section{METODE PENELITIAN}

Metode yang digunakan pada penelitian iniyaitu metode yuridisnormatif dengan pendekatanyang dilakukan berdasar pada bahan hukum utama dengan cara menelaah teori - teori, asas - asas hukum (Zaini, 2011), konsep serta menganalisis perundang - undangan yangada hubungannya dengan istilah ini sehingga dapat mengetahui secara lebih dalam yang dimaksud dengan Atribusi, Del egasi dan Mandat. Disamping itu, penelitian ini menggunakan metode kualitatif untuk melakukan penelitian ini dengan menggunakan studi pustaka dan dari beberapa sumber yang sesuai dengan penelitian ini (Sugiyono, 2011).

\section{HASIL DAN PEMBAHASAN}

\section{Pengertian Atribusi, Delegasi, dan Mandat}

Menurut Ridwan (2016) dalam bukunya yang berjudul Hukum Administrasi Negara. hal. 101. menjelaskan Yaitu bahwa pilar utama negara hukum yaitu asas legalitas maka berdasarkan prinsip ini tersirat bahwa kewenangan pemerintah berasal dari peraturan perundang-undangan, yaitu sumber kewenangan bagi pemerintah yaitu peraturan perundang-undangan, Secara teori wewenang yang 
bersumber dari peraturan perundang-undangan tersebut diperoleh melalui tiga cara yaitu kewenangan yang diperoleh melalui atribusi, kewenangan yang diperoleh melalui delegasi dan kewenangan yang diperoleh dari mandat.

Kewenangan yang didapat dari atribusi mutlak berasal dari amanat undang-undang yang secara eksplisit langsung terdapat dari redaksi undang-undang atau pasal tertentu (Fitri, 2019), dan penerima atribusi dapat memperluas bidang atribusi dan memperluas wewenang baru yang telah didapat sejauh tidak melewati bidang kewenangan, kewenangan atribusi akan tetap lekat selama tidak ada perubahan peraturan perundang-undangan, secara mutlak tanggung jawab dan tanggung gugat kepada penerima atribusi, hubungan hukum wewenang antara pembentuk undang-undang dengan organ/badan pemerintahan, sedangkan dalam delegasi tidak dapat menciptakan dan memperluas wewenang yang ada hanya pelimpahan wewenang dari organ/badan dan atau pejabat pemerintahan lain dan secara yuridis tanggung jawab delegasi berpindah daripemberi ke penerima delegasi.Penerima delegassi bertanggung jawab kepada pemberi delegasi serta dapat dicabut atau ditarik kembali jika terdapat penyalahgunaan dan atau penyimpangan yang dilakukan oleh penerima delegasi, berdasar kewenangan atribusi yang diberikan oleh pemberi delegasi kepada penerima delegasi (delegataris), mandat yaitu diperoleh dari pelimpahan wewenang yang diberikan dari pemberi mandat kepada penerima mandat (mandataris) biasanya terdapat di dalam intern pemerintahan biasa terjadi antara atasan dan bawahan kemudian mandat dapat ditarik kembali atau digunakan sewaktu-waktu oleh pemberi kewenangan sedangkan tanggungjawab dan tanggung gugatberada pada pemberimandat.

Menurut Indroharto (1993) di dalam bukunya Usaha Memahami Undang-Undang Tentang Peradilan Tata Usaha Negara. hal.90 ). menjelaskan yaitu bahwa rumusan berdasarkan peraturan peraturan perundang-undangan yang berlaku, selain mengandung makna untuk keabsahan (legalitas) dari setiap kewenangan pemerintah yang dijalankan oleh organ/badan atau pejabat tata usaha negara juga menunjukan bahwa kewenangan pemerintah berasal dari peraturan perundang-undangan yang berlaku saja.

Undang - Undang no. 30 tahun 2014 berbunyi yaitu kewenangan diperoleh melalui atribusiadalah kewenangan yang diberikan kepada organ/badan dan atau pejabat pemerintah oleh Undang-Undang Dasar negara RI tahun 1945 atau Undang - Undang, Wewenang atribusi tidak boleh di delegasikan kecuali diatur oleh Undang - Undang Dasar. Sedangkan kewenangan yang diperoleh melalui delegasi yaitu pelimpahan wewenang dari organ/badan dan atau pejabat pemerintah kepada organ/badan atau pejabat pemerintah yang bertanggung jawab begitu juga tanggunggugat sepenuhnya berpindah kepada penerima delegasi dan dikukuhkan melalui aturan pemerintah, keputusan Presiden (KEPRES) dan atau Peraturan Daerah (PERDA) adalah kewenangan pelimpahan dan sebelumnya telah ada. wewenang yang diperoleh melalui delegasi tidak dapat dilimpahkan lagi kepada organ/badan dan atau pejabatpemerintah yang lain kecuali diatur melalui Undang - Undang, didalam hal diatur melalui Undang - Undang. organ/badan dan atau pejabat pemerinntah yang mendapat kewenangan dapat mensub delegasikan tindakan ke organ/badan dan atau pejabat pemerintah lain dengan ketetapan diterapkan berbentuk aturan sebelum kewenangan dilaksanakan, dilaksanakan di dalam pemerintah itu sendiri dan paling banyak diberikan kepada organ/badan dan atau pejabat pemerintah satu tingkat dibawahnya. Organ/Badan dan atau pejabat pemerintah yang melimpahkan delegasi bisa menggunakan sendiri wewenangnya yang sudah dilimpahkan melalui delegasi kecuali ditentukan lain oleh peraturan Undang - Undang. Apabila penerpan kewenangan melalui delegasitidak efektif maka organ/badan dan atau pemerintah yang mendelegasikan bisa ditarik lagi kewenangan yang sudah di delegasikan. 
Organ/Badan dan atau pejabat pemerintah penerima delegasi (delegataris) bertanggung jawab atas delegasiyang diterimanya. Kemudian kewenangan yang diperoleh melalui mandatialah pelimpahan wewenang dari Organ/badan dan atau pejabat pemerintah yang lebih tinggi kedudukanya kepada organ/badan dan atau pejabat pemerintah yang lebih rendah kedudukanya (mandataris) dengan tanggungjawab dan tanggunggugat tetap kepada pemberi mandat (Falah, 2015). Organ/Badan dan atau pejabat pemerintah mendapat mandat jika ditugaskan oleh Organ/badan atau pejabat pemerintah diatasnya dan sebagai pelaksana tugas rutin, organ/badan dan atau pejabat yang melaksanakan tugas rutin tersebut diatas yaitu tugas rutin dari pejabat definitif yang berhalangan sementara dilaksanakan oleh pelaksana harian. Organ/Badan dan atau pejabat pemerintah menndapat mandat bila diberi tugas oleh organ/badan atau pejabat pemerintah diatasnya dan sebagai pelaksana tetap, pelaksana tugas tetap tersebut diatas adalah pejabat definitive yang berhalangan tetap dilaksanakan oleh pelaksana harian yang melaksanakan tugas tetap. Badan dan atau pejabat pemerintah mendapat mandat bila ditugaskan oleh organ/badan atau pejabat pemerintah diatasnya dan merupakan pelaksanaan tugas rutin kecuali ditentukan lain dalam peraturan Undang - Undang. Organ/Badan dan atau pejabat pemerintah penerima mandat harus menyebutkan atas nama Organ/badan dan atau pejabat pemerintah yang memberikan mandat. wewenang yang telah diberikan melalui mandat oleh Organ/badan dan atau pejabat pemerintah yang telah diberikan dapat menggunakan sendiri kecuali ditentukan lain dalam peraturan Undang Undang. Bila mandat yang telah diberikan menimbulkan ketidakefektifan penyelenggaraan pemerintah dalam melaksanakan kewenangan, organ/badan dan atau pejabat dapat menarik kembali mandat yang sudah diberikan. keputusan dan atau tindakan bersipat strategis yang mengakibatkan pada perubahan status hukum pada aspek organisasi, kepegawaian, dan alokasi anggaran tidak boleh diambil atau diputuskan oleh Organ/Badan dan atau pejabat pemerintah yang medapat kewenangan dari mandat. Tanggung jawab kewenangan tetap pada pemberi mandat atas kewenangan organ/Badan dan atau pejabat pemerintahanyang memperoleh wewenang melalui mandat (Darda Syahrizal,2018).

\section{Batasan Kewenangan}

Kewenangan organ/badan dan atau pejabat pemerintah dibatasi masa atau tenggang waktu kewenangan. Wewenang badan dan pejabat pemerintah dibatasi oleh wilayah atau daerah berlakunya wewenang . kewenangan organ/badan dan atau pejabat pemerintah dibatasi lingkup bidangatau materi kewenangan. Wewenang organ/badan dan atau pejabat pemerintah dibatasi oleh masa dan tenggang waktu wewenang.

\section{Sengketa Kewenangan}

Organ/Badan dan atau pejabat pemerintah mencegah terjadinya sengketa kewenangan dalam menjalankan wewenang, dan jika terjadi sengketa wewenang dilingkungan pemerintah, wewenang menyelesaikan sengketa kewenangan ada antar atasan pejabat pemerintah yang bersengketa yaitu melalui koordinasi untuk menghasilkan mupakat, kecuali ditentukan lain dalam ketentuan peraturan Undang - Undang. dan jika terjadi sengketa wewenang di lingkungan pemerintah, wewenang menyelesaikan sengketa kewenangan ada antar atasan pejabat pemerintah yang bersengketa yaitu melalui koordinasi untuk menghasilkan mupakat maka mupakat tersebut mengikat para pihak yang bersengketa sepanjang tidak merugikan Uang Negara, asset Negara dan atau lingkungan hidup dan jika terjadi sengketa wewenang di lingkungan pemerintah, wewenang menyelesaikan sengketa kewenangan ada antar atasan pejabat pemerintah yang bersengketa yaitu melalui koordinasi untuk menghasilkan mupakat tetapi tidak menghasilkan mupakat maka penyelesaian sengketa wewenang dilingkungan 
pemerintah pada tingkat terakhir diputuskan oleh Presiden (Darda Syahrizal, 2018). Apabila terjadi sengketa wewenang di lingkungan pemerintahan, wewenang penyelesaian sengketa kewenangan ada pada antar atasan pejabat pemerintah yang bersengketa melalui koordinasi untuk menghasilkan mupakat tetapitidak menghasilkan mupakat maka penyelesaian sengketa wewenang dilingkungan pem erintahan yang melibatkan lembaga Negara diselesaikan oleh Mahkamah Konstitusi. Apabila ada konflik wewenang dilingkungan pemerintah, wewenangan menyelesaikan konflik wewenang diselesaikan antar atasan pejabat pemerintah yang mengalami konflik dengan berkoordinasi demi mencapai mupakat tetapi tidak ada mupakat maka konflik wewenang dilingkungan pemerintah dalam hal konflik wewenang mengakibatkan kerugian uang Negara, asset Negara, dan lingkungan hidup, konflik tersebut penyelesainya berpedoman pada ketentuan peraturan Undang- Undang.

\section{Larangan Penyalahgunaan Kewenangan}

1. Organ/Badan danatau pejabat pemerintah dilarangmenyalahgunakan kewenangan apabila sudah melewati kewenangan yang sudah ditetapkan, Organ/badan dan atau pejabat pemerintah dilarang menyalah gunakan kewenangan. Apabila sudah melewati kewenangan dapat dibatalkan. jika telah diuji dan ada putusan Pengadilan yang berkekuatan hukum tetap.

2. Organ/badan dan atau pejabat pemerintah dilarang menyala hgunakan kewenangan. Apabila sudah melewati wewenang yang sudah ditetapkan tidak sah jika telah di uji dan ada putusan Pengadilanyangmempunyai kekuatan hukum tetap.

3. Organ/badan dan atau pejabat pemerintah dilarang menyalahgunakan kewenangan apabila bertindak sewenang-wenang, Organ/badan dan atau pejabat pemerintah dilarang menyalahgunakan kewenangan. Apabila bertindak sewenang - wenang tidak sah bila sudah di uji dan ada keputusan pengadilanyang mempunyai kekuatan hukum tetap,

4. organ/badan dan atau pejabat pemerintah dilarang menyalahgunakan kewenangan dengan mencampuradukan wewenang bila putusan dan atau tindakan yang dilakukan diluar lingkup atau cakupan bidang atau materi kewenangan yang diberikan.

5. Organ/Badan dan atau pejabat pemerintah dilarang menyalahgunakan wewenang dengan mencampuradukan kewenangan bila putusan dan atau tindakan yang dilakukan diluar lingkup atau cakupan bidang atau materi kewenangan yang diberikan bisa dibatalkan bila sudah diuji dan ada putusan pengadilan yang mempunyai kekuatan hukum tetap.

6. Organ/Badan dan atau pejabat pemerintah dilarang menyalahgunakan kewenangan dengan mencampuradukan kewenangan bisa dibatalkan bila sudah diuji dan ada putusan pengadilan yang mempunyai kekuatan hukum tetap (Hakim, 2011).

7. Organ/Badan dan atau pejabat pemerintah dilarang menyalahgunakan kewenangan dengan mencampuradukan wewenang bila putusan dan atau tindakan yang dilakukan bertentangan dengan tujuan yang diberikan. Badan dan atau pejabat pemerintah dilarang menyalahgunakan wewenang dengan mencampuradukan kewenangan bila putusan dan atau tindakan yang dilakukan bertentangan dengan tujuan yang diberikan bisa dibatalkan bila sudah diuji dan ada putusan pengadilan yang mempunyai kekuatan hukum tetap.

8. Organ/Badan dan atau pejabat pemerintah dilarang menyalahgunakan kewenangan dengan cara bertindak sewenang - wenang apabila keputusan dan atau tindakan yang dilakukan tanpa dasar kewenangan. 
9. Badan atau pejabat pemerintah dilarang menyalahgunakan wewenang dengan cara bertindak sewenang-wenang bisa dibatalkan bila telah diuji dan telah diputus oleh pengadilan yang mempunyai kekuatan hukum tetap.

10. Organ/Badan dan atau pejabat pemerintah dilarang menyalahgunakan kewenangan dengancara melakukan tindakan sewenang-wenang bila putusan dan tindakan yang dilakukan tidakada dasar kewenangan tidak sah bila sudah di uji dan ada putusan pengadilan yang mempunyai kekuatan hukum tetap.

11. Organ/Badan dan atau pejabat pemerintah dilarang menyalahgunakan kewenangan dengancara bertindak sewenang - wenang bila putusan dan tindakan yang dilakukan bertentangan dengan keputusan pegadilan yang mempunyai kekuatan hukum tetap,

12. Badan dan atau pejabat pemerintah apabila keputusan dan atau tindakan yang dilakukan melampaui masa jabatan atau batas waktu berlakunya kewenangan dikategorikan melampaui waktu kewenangan. Badan dan pejabat pemerintah bila keputusan dan atau tindakan yang dilakukan melewati masa jabatan atau batas waktu berlakunya wewenang dikategorikan melampaui kewenangan tidak sah bila sudah di ujidan ada putusan pengadilan yang mempunyai kekuatanhukum tetap.

13. Organ/Badan dan atau pejabat pemerintah bila melewati batas wilayah berlakunya kewenangan dikategorikan melewati kewenangan. Organ/Badan dan atau pejabat pemerintah bila melewati batas wilayah berlakunya kewenangan dikategorikan melewati kewenangan tidak sah bila sudah di uji dan ada putusan pengadilan yang berkekuatan hukum tetap.

14. Organ/Badan dan pejabat pemerintah bila bertentangan dengan ketentuan peraturan Undang Undang dikategorikan melewati kewenangan.

15. Organ/Badan dan pejabat pemerintah bila bertentangan dengan ketentuan peraturan Undang Undang dikategorikan melewati kewenangan tidak sah bila sudah di uji dan ada putusan pengadilan yang mempunyai kekuatan hukum tetap.

\section{Pengawasan kewenangan}

Pengawasan kepada larangan penyalah gunaan kewenangan baik larangan melampaui kewenangan, larangan mencampuradukan kewenangan, larangan melakukan tindakan sewenangwenang, larangan lewati masa jabatan atau batas waktu berlaku kewenangan, lewat batas kewilayahan berlakunya kewenangan, bertentangan dengan ketentuan Undang - Undang diluar cakupan lingkup bidang atau materi kewenangan yangsudah diberikan (Eddyono, 2016).

Bersebrangan dengan tujuan kewenangan yang diberikan tidak ada dasar kewenangan, bersebrangan dengan putusan pengadilan yang berkekuatan hukum tetap dilakukan oleh petugas/aparat pengawas intern pemerintahan, hasil pengawasan petugas/aparat intern pemerintahan yang dimaksud diatas yaitu berupa tidak ada kesalahan, ada kesalahan administratif, kesalahan administratif yang mengakibatkan kerugian uang Negara. Jika hasil dari pengawasan petugas/aparat intern pemerintahan yang dimaksud diatas ada kesalahan administratif dilakukan tindakan dalam bentuk yaitu penyempurnaan administratif sesuai ketentuan Undang - Undang, hasil dari pengawasan petugas/aparat intern pemerintahan yang dimaksud diatas yaitu berupa tidak terdapat kesalahan, adanya salah administratif, kesalahan administrative yang timbul mengakibatkan kerugian uang Negara maka dikembalikanya uang Negara paling lama 10 hari kerja terhitung sejak adanya putusan dan diterbitkanya hasil pengawasan, dikembalikanya kerugian Negara yang dimaksud diatas dibebankan kepada badan pemerintah bila kesalahan administratif yang timbul menyebabkan kerugian negaraterjadi karena bukan 
karena unsur penyalahgunaan wewenang, pengembalian kerugian negara yang dibebankan kepada pejabat pemerintah bila kesalahan administratif yang timbul menyebabkan kerugian negara terjadi karena adanya unsur penyalahgunaan kewenangan, pengadilan berwenang menerima laporan penyelahgunaan wewenang, memeriksa laporan, dan atau menetapkan ada atau tidak adanya penyalahgunaan kewenangan yang dilakukan oleh pejabat pemerintah, organ/badan dan atau pejabat pemerintah boleh mengajukan permohonan ke pengadilan untuk menimbang ada atau tidak adanya penyalahgunaan kewenangan dalam keputusan dan atau tindakan dan pengadilan wajib memutuskan permohonan yang diajukan pejabat pemerintah tersebut diatas paling lama 21 hari kerja sejak permohonan diajukan. Terhadap putusan yang diputuskan oleh pengadilan berkenaan dengan pemohonan yang diajukan pejabat pemerintah tersebutdiatas dapat mengajukan banding ke Pengadilan TUN dan Pengadilan Tinggi TUN wajib memutus permohonan banding paling lama 21 hari kerja sejak permohonan banding diajukan. Putusan Pengadilan Tinggi TUN tersebut diatas bersifat final dan mengikat (Hakim,2011).

\section{SIMPULAN}

Setiap negara memiliki sistem administrasi yang dipedomani tidak terkecuali di sistem permerintahan di negara RI a da teoriyang dikenal dengan namanya atribusi, delegasi, dan mandat, teori dimaksud yaitu sistem kewenangan yang diberikan negara dan diatur demi menjalankan dan menciptakan pemerintahan yang baik (good government). Disamping itu, Wewenang organ/badan atau pejabat pemerintah terdapat pembatasan wewenang yang dikaitkan dengan masa berlakunyawewenang dan batasan wilayah wewenang, cakupan bidang atau materi wewenang, organ/Badan atau pejabat pemerintah harus mencegah terjadi sengketa kewenangan dalam menjalankan wewenang, dan apabila terjadi sengketa kewenangan di lingkungan pemerintah, wewenang penyelesaian sengketa kewenangan berada pada antar atasan pejabat pemerintah yang bersengketa melalui koordinasi untuk menghasilkan mupakat, kecuali ditentukan lain dalam ketentuan peraturan Undang - Undang, maka mupakat tersebut mengikat para pihak yang bersengketa selama tidak merugikan uang negara, asset negara dan atau lingkungan hidup, apabila tidak ada mupakat selanjutnya diputus oleh Presiden, dan apabila terjadi sengketa wewenang dilingkungan pemerintah, wewenang menyelesaikan sengketa wewenang berada antara atasan pejabat pemerintah yang bersengketa dengan koordinasi untuk mupakat tetapi tidak menghasilkan mupakat maka penyelesaian sengketa kewenangan dilingkungan pemerintahan yang ada pada Organ/Badan/lembaga Negara diselesaikan oleh Mahkamah Konstitusi (MK). Apabila ada konflik wewenang pada pemerintahan, kewenangan menyelesaikan konflik wewenang yaitu ada antara atasan pejabat pemerintah yang mengalami konflik dengan berkoordinasi untuk mupakat tetapi jika tidak menemukan mupakat maka konflik wewenang diselesaikan dilingkungan pemerintah apabila konflik wewenang mengakibatkan kerugian uang Negara, asset Negara, dan lingkungan hidup, konflik tersebut diselesaikan sesuai ketentuan peraturan Undang - Undang. Organ/Badan dan atau pejabat pemerintah tidak boleh menyalahgunakan kewenangan. Apabila sudah melewati kewenangan yang sudah ditetapkan, tindakannya tidak sesuai kewenangan, bertindak diluar lingkup bidang atau materi wewenang mencampuradukan wewenang, melewati masa jabatan atau batas waktu berlakunya kewenangan, melewati batas wilayah berlakunya kewenangan, dapat dibatalkan. Apabila telah diuji dan ada putusan pengadilan yang berkekuatan hukum, tidak sah apabila suadh di uji dan ada putusan pengadilan yang berkekuatan hukum ttetap. Aparat pengawas intern pemerintah melakukan pengawasan, pengadilan berwenang menerima laporan penyelahgunaan wewenang memeriksa laporan, dan atau memutuskan ada atau tidak adanya unsur penyal ahgunaan kewenanganyang dilakukan oleh pejabat pemerintah dapat 
mengajukan banding ke Pengadilan Tinggi TUN dan Putusan Pengadilan Tinggi TUN terseb ut diatas bersifat final dan mengikat.

\section{DAFTARPUSTAKA}

Adiwilaga, R., Alfian, Y., \& Rusdia, U. (2018). Sistem Pemerintahan Indonesia. Deepublish.

Azhar, M. (2015). Relevansi asas-asas umum pemerintahan yang baik dalam Sistem penyelenggaraan administrasi Negara. NOTARIUS, 8(2), 274-286.

Darda Syahrizal, S. H. (2018). Hukum Administrasi Negara \& Peradilan Tata Usaha Negara. Media Pressindo.

Eddyono, L. W. (2016). Penyelesaian Sengketa Kewenangan Lembaga Negara oleh Mahkamah Konstitusi. Jurnal Konstitusi, 7(3), 1-48.

Falah, R. G. (2015). Kedudukan, Tugas Dan Wewenang Wakil Kepala Daerah Dalam Pemerintahan Daerah Pasca Reformasi di Indonesia. Universitas Islam Indonesia.

Fitri, R. R. (2019). Kajian Yuridis Kewenanganmajelis Permusyawaratan Rakyat Dalam Penetapan Kebijakan Rencana Pembangunan Nasional.

Hakim, L. (2011). Kewenangan organ negara dalam penyelenggaraan pemerintahan. Jurnal Konstitusi, 4(1).

HSB, A. M., \& JULIANTHY, E. M. (2019). Pelaksanaan Kewenangan Atribu si Pemerintahan Daerah Berdasarkan Undang-Undang Nomor 23 Tahun 2014 Tentang Pemerintahan Daerah.Jurnal Legislasi Indonesia, 152.

Indroharto. (1993). Usaha memahami undang-undang tentang peradilan tata usaha negara: Buku 1. Beberapa pengertian dasar hukum tata usaha negara. Pustaka Sinar Harapan.

Ridwan, H. R. (2016). Hukum Administrasi Negara, Ed. Revisi, -cet. 9. Jakarta: Rajawali Pers.

Rokhim, A. (2013). Kewenangan Pemerintahan Dalam Konteks Negara Kesejahteraan (Welfare State).Jurnal Ilmiah Ilmu Hukum Dinamika Hukum, 136.

Sastra, I. (2017). CHECK AND BALANCES KEKUASAAN LEMBAGA NEGARA GUNA MENATA PEMERINTAHAN YANG BAIK (GOOD GOVERNMENT). Jurnal Hukum Replik, 5(2), 184-199.

Sugiyono, P. (2011). Metodologi penelitian kuantitatif kualitatif dan R\&D. Alpabeta, Bandung.

Wicaksono, A., \& Purbawa, Y. (2018). Hutang negara dalam reforma agraria studi implementasi mandat 9 juta hektar tanah Indonesia. BHUMI:Jurnal Agraria Dan Pertanahan, 4(1), 24-38.

Zaini, Z. D. (2011). Implementasi pendekatan yuridis normatif dan pendekata n normatif sosiologis dalam penelitian ilmu hukum. Pranata Hukum, 6(2), 26707. 